\title{
Plants used traditionally to treat malaria in Brazil: the archives of Flora Medicinal
} Alexandros S Botsaris*

\author{
Address: IBPM (Brazilian Institute of Medicinal Plants), Rua Gal Urquiza 128, Rio de Janeiro, RJ, 22431-040, Brazil \\ Email: Alexandros S Botsaris* - ibpm@ibpm.org.br \\ * Corresponding author
}

Published: I May 2007

Journal of Ethnobiology and Ethnomedicine 2007, 3:18 doi:10.1186/1746-4269-3-18

This article is available from: http://www.ethnobiomed.com/content/3/1/18

(c) 2007 Botsaris; licensee BioMed Central Ltd.

This is an Open Access article distributed under the terms of the Creative Commons Attribution License (http://creativecommons.org/licenses/by/2.0), which permits unrestricted use, distribution, and reproduction in any medium, provided the original work is properly cited.
Received: 9 January 2006

Accepted: I May 2007

\begin{abstract}
The archives of Flora Medicinal, an ancient pharmaceutical laboratory that supported ethnomedical research in Brazil for more than 30 years, were searched for plants with antimalarial use. Forty plant species indicated to treat malaria were described by Dr. J. Monteiro da Silva (Flora Medicinal leader) and his co-workers. Eight species, Bathysa cuspidata, Cosmos sulphureus, Cecropia hololeuca, Erisma calcaratum, Gomphrena arborescens, Musa paradisiaca, Ocotea odorifera, and Pradosia lactescens, are related as antimalarial for the first time in ethnobotanical studies. Some species, including Mikania glomerata, Melampodium divaricatum, Galipea multiflora, Aspidosperma polyneuron, and Coutarea hexandra, were reported to have activity in malaria patients under clinical observation. In the information obtained, also, there were many details about the appropriate indication of each plant. For example, some plants are indicated to increase others' potency. There are also plants that are traditionally employed for specific symptoms or conditions that often accompany malaria, such as weakness, renal failure or cerebral malaria. Many plants that have been considered to lack activity against malaria due to absence of in vitro activity against Plasmodium can have other mechanisms of action. Thus researchers should observe ethnomedical information before deciding which kind of screening should be used in the search of antimalarial drugs.
\end{abstract}

\section{Background}

Flora Medicinal is an ancient and small pharmaceutical laboratory established, in early 1915, by Mr. José Monteiro da Silva, a Medical Doctor in Rio de Janeiro. Mr. Monteiro da Silva was an idealist who believed that the Brazilian rainforest had an enormous potential for research and discovery of new drugs. For more than 40 years Mr. Monteiro da Silva had organized a group of technicians and scientists who made a great number of excursions into Brazilian rainforest, collecting plant specimens and information. Although he had also edited the Revista da Flora Medicinal, a scientific paper in which he described his discoveries, a considerable part of his research remains unpublished. During the '30 s and '40 s, the Revista da Flora Medicinal was translated to French and republished by the Institut Pasteur, in Paris, which allowed some of his findings to be used by the international pharmaceutical industry. During his activities, Mr. Monteiro da Silva and his team described more than 200 new medicinal plants from this region. One of his targets was the study of new antimalarial plants, as at his time malaria was a concerning health problem in Brazil. In the following years, quinine, its derivatives and other drugs helped to control malaria. Nowadays, however, its incidence is again growing worldwide, and Plasmodium falciparum is getting more resistant to the usual antimalarial 
drugs[1]. It is estimated that $62 \%$ of $P$. falciparum around the world presents with mono or multiresistant drug profile[1]. The World Health Organization estimates that there are between 300 and 500 million new cases of malaria worldwide, every year, mostly in Africa, Asia, South Pacific Islands and South America, which causes, at least, 3 million deaths $[2,3]$. The main drugs developed for malaria and used up to now (quina alkaloids derived drugs and artemisinin) were discovered based on traditional use and ethnomedical data[4,5]. New efforts to search for novel drugs for treating malaria are very important in countries like Brazil, where many endemic areas still exist[6]. The study of well-documented data such as the archives of Flora Medicinal can point out traditional and probably effective treatments that had not been yet subjected to testing.

\section{Materials and methods}

All documents, including books, hand notes, unpublished studies and the issues of Revista da Flora Medicinal, belonging to the library of Mr. Monteiro da Silva, were examined for information about botanical therapies and plant species used for malaria. Any data or references to plants used for malaria were carefully inserted into a template, and botanical name and classification were reexamined and confirmed with four major plant databases - The Missouri Botanical Garden's VAST[7], the International Plant Names Index[8], the New York Botanical Garden vascular plants database[9] and the Brazilian's Northeast Plants Database[10]. Other information existing in modern databases such as Pubmed (U.S. National Library of Medicine's database that is searchable on the Web) were also examined and compared to other ethnopharmacological studies and current published data.

A review of plants with possible antimalarial activity reported in ethnomedical studies or in pharmacological and biochemical research was also made [11-31].

\section{Results}

The results are summarized on Table 1. Forty [40] plants with possible antimalarial activity were reported and examined by Dr. Monteiro da Silva and his co-workers. The plants were identified by scientific names and families, as well as by vernacular names and usual translations to English, if existent. For each of the species, the parts used for general conditions and symptoms and for treating malaria, as gathered from ethnomedical reports published in Flora Medicinal, are listed. Scientific data about in vitro and in vivo research are also provided.

Most plants, like Bidens pilosa, Cantharanthus roseus, Cassia fistula, Cinchona calisaya, Cuphea ingrata, Geissospermum sericeum, Jateorrhiza palmata, Quassia amara, Simaba ferruginea, and Strychnos pseudoquina, were already reported as antimalarial in previous ethnobotanical studies. Some of these had also their activity against Plasmodium tested, as shown on Table 1. Eight species are reported as antimalarial for the fist time: Bathysa cuspidata, Cosmos sulphureus, Cecropia hololeuca, Erisma calcaratum, Gomphrena arborescens, Musa paradisiaca, Ocotea odorifera, and Pradosia lactescens.

A greater proportion of the plants reported as antimalarial belong to the families Asteraceae (six species), Rubiaceae (five), Apocynaceae (four), and Simaroubaceae (four).

\section{Discussion}

Most research for antimalarial new drugs is only focused on direct activity against Plasmodium species. But attention to ethnomedical information gathered by Monteiro da Silva suggests that other effects should be investigated. For example, some plants are referred to enhance the action of other herbs, which can indicate an increase on permeability of the Plasmodium membrane to antiparasitic substances, or an inhibition of pump mechanisms of eliminating the drugs $[58,59]$. Considering that one of the common mechanisms of drugs resistance is the reduction of permeability, the development of drugs that enhance parasite permeability could be of valuable help in the treatment of infectious diseases[60,61]. Other possible mechanism of action is interference with parasite enzymes used for protection against antiparasitic drugs[62].

Some plants with noticeable ethnopharmacological use in malaria showed only weak or even no activity against Plasmodium in vitro[55]. For example, Mikania glomerata, Melampodium divaricatum, Galipea multiflora, Aspidosperma polyneuron, and Coutarea hexandra had their antimalarial activity confirmed by clinical observations of medical doctors (Table 1), an information that yields a high probability of accuracy.

Some authors have underestimated the traditional plants used for malaria based exclusively on low activity against Plasmodium in vitro or in animal models[55]. This can be a mistake of strategy or even methodology.

There are many explanations for the absence of in vitro activity of an effective antimalarial drug. As an example, the active principle could be formed by hepatic metabolism, or as a result of transformation by gut bacteria. Other possible mechanisms of action include immunomodulation or interference with the invasion of new red blood cells by parasites, which can be species specific. Therefore studies in human subjects, as well as the observance of ethnomedical detailed data, are urged in order to exclude or confirm the activity of herbs traditionally used to treat malaria. 
Table I: Plants with possible antimalarial activity gathered from ethnomedical reports published in Flora Medicinal

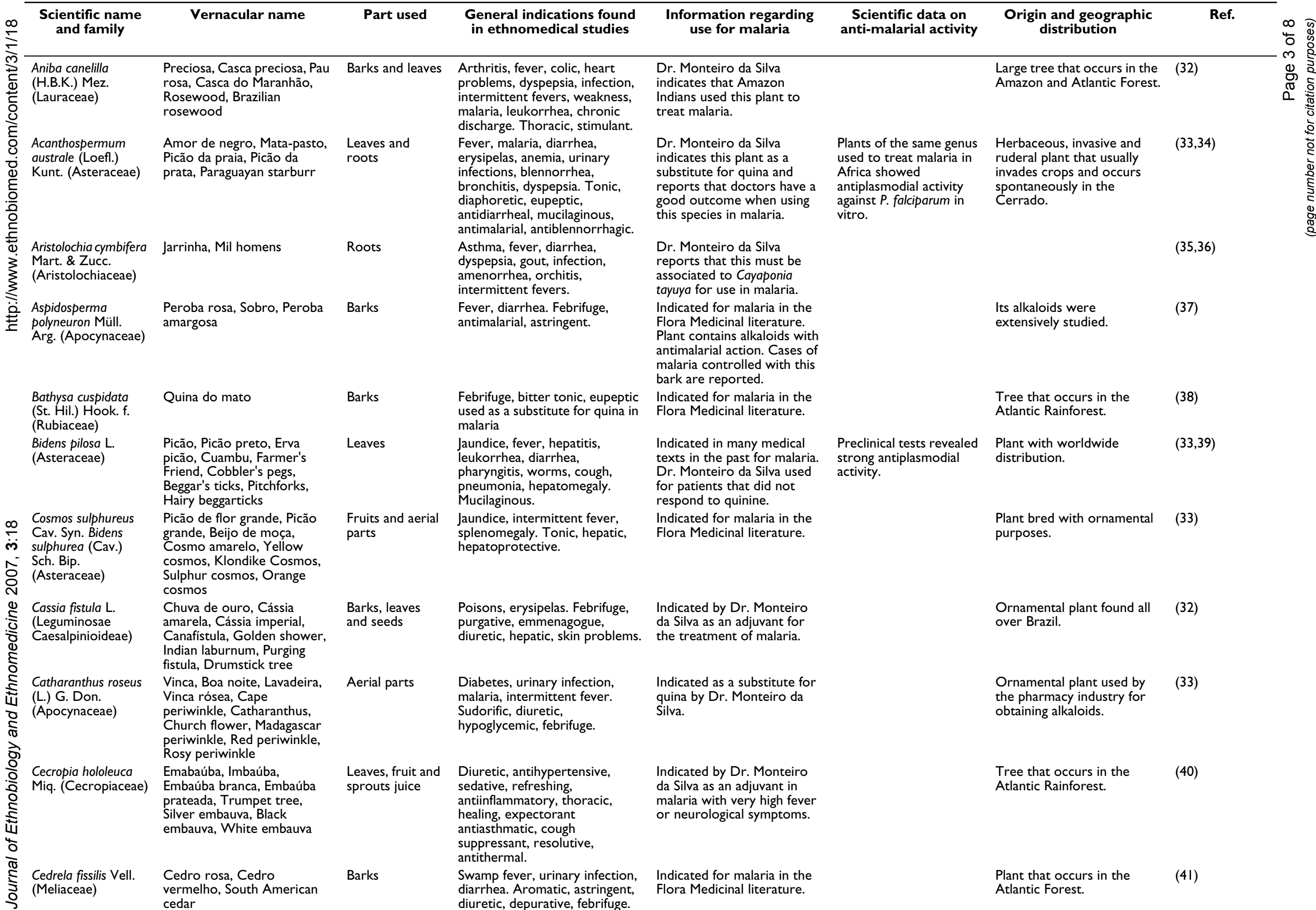


Table I: Plants with possible antimalarial activity gathered from ethnomedical reports published in Flora Medicinal (Continued)

\begin{tabular}{|c|c|c|}
\hline $\begin{array}{l}\text { Chondodendron } \\
\text { platyphyllum (St. } \\
\text { Hill.) Miers. } \\
\text { (Menispermaceae) }\end{array}$ & $\begin{array}{l}\text { Quina peruana, Casca dos } \\
\text { jesuítas, Quina verdadeira, } \\
\text { Ledger quinine, Calisaya, } \\
\text { Jesuit's powder, Yellow } \\
\text { cinchona }\end{array}$ & $\begin{array}{l}\text { Roots, barks and } \\
\text { leaves }\end{array}$ \\
\hline $\begin{array}{l}\text { Coffea arabica L. } \\
\text { (Rubiaceae) }\end{array}$ & $\begin{array}{l}\text { Café, Cafeeiro, Coffee, } \\
\text { Arabica coffee, Arabian } \\
\text { coffee, Abyssinian coffee, } \\
\text { Brazilian coffee }\end{array}$ & $\begin{array}{l}\text { Leaves and } \\
\text { seeds }\end{array}$ \\
\hline $\begin{array}{l}\text { Coutarea hexandra } \\
\text { (Jacq.) Schum. } \\
\text { (Rubiaceae) }\end{array}$ & $\begin{array}{l}\text { Quina-quina, Quina-brava, } \\
\text { Quina-de-pernambuco, } \\
\text { Quineira, Murta do mato }\end{array}$ & Barks \\
\hline $\begin{array}{l}\text { Cuphea ingrata } \\
\text { Hoehne } \\
\text { (Lythraceae) }\end{array}$ & $\begin{array}{l}\text { Sete sangrias, Perna de } \\
\text { saracura, Mata cana, Pega } \\
\text { pinto }\end{array}$ & $\begin{array}{l}\text { Aerial parts and } \\
\text { whole plant }\end{array}$ \\
\hline $\begin{array}{l}\text { Dipteryx odorata } \\
\text { (Aublet) Willd. } \\
\text { (Fabaceae) }\end{array}$ & $\begin{array}{l}\text { Fava de Tonka, Faveira de } \\
\text { cheiro, Imburana de cheiro, } \\
\text { Cumaru de cheiro, Cumaru } \\
\text { de folha grande, Tonka bean, } \\
\text { Cumaru, Coumarou, } \\
\text { Tonquin bean }\end{array}$ & Seeds \\
\hline $\begin{array}{l}\text { Elephantopus mollis } \\
\text { Kunth. (Asteraceae) }\end{array}$ & $\begin{array}{l}\text { Erva grossa, Língua de vaca, } \\
\text { Pé de elefante, Elephantopus, } \\
\text { Elephant's foot, False } \\
\text { tobacco, Tobacco weed }\end{array}$ & Aerial parts \\
\hline $\begin{array}{l}\text { Erisma calcaratum } \\
\text { (Link) Warm. } \\
\text { (Vochysiaceae) }\end{array}$ & $\begin{array}{l}\text { Jaboti, Erva de Jaboti, Jabuti, } \\
\text { Jabuti-araconha, Jabuti da } \\
\text { várzea, Jaboty, Jaboty palm }\end{array}$ & Fruits \\
\hline $\begin{array}{l}\text { Esenbeckia febrifuga } \\
\text { (St. Hil.) A. Juss. ex } \\
\text { Mart. (Rutaceae) }\end{array}$ & $\begin{array}{l}\text { Quina do mato, Angustura, } \\
\text { Gumarim }\end{array}$ & Barks \\
\hline $\begin{array}{l}\text { Galipea multiflora } \\
\text { Schultz (Rutaceae) }\end{array}$ & $\begin{array}{l}\text { Quina falsa, Jasmim do mato, } \\
\text { Ticoró, Guamixinga }\end{array}$ & Barks \\
\hline
\end{tabular}

Gases, colic, diarrhea,
abdominal pain, verminosis,
fever, emesis, nausea, infection,
bronchitis, amenorrhea,
intermittent fever.
Antiasthmatic, bitter tonic,
eupeptic.
Fever, malaria, eczema. Hair
tonic.

Colds, intermittent fever.
Clears the blood, diuretic,
stimulant, antiasthmatic,
digestive, hypoglycemic.
Intermittent fever, gallbladder
stones or problems, digestive
problems, colic. Antithermal,
antimalarial.

Use by Indians from the

treating malaria, reported by

Dr. Monteiro da Silva.

Used as the main source of quinin by Dr. Monteiro da

Silva. It has quinolinic and

quinin derivatives in its

composition.

Dr. Monteiro da Silva used

the leaves decoction to

potentiate other plants with

activity.

Dr. Monteiro da Silva relates

this plant as one of the

substitutes for quina and
reports cases of malaria cure

reports cases of malaria cure
with its use, some described

with its use, some described
in the book Botânica Médica in the book Botânica Médica Dias da Rocha.

High blood pressure, syphilis,
dermatoses, intermittent fever, $\begin{array}{ll}\text { dermatoses, intermittent fever, } & \text { Flora Medicinal literature. } \\ \text { stomachache, rheumatism, } & \text { According to Dr. Monteiro }\end{array}$ venereal diseases, urethra discharge. Depurative, antisyphilitic, cholesterolreducing, antihemorrhagic, mucous membrane protector, tonic, analgesic. cerebral complications in
severe cases.

Antispasmodic, emmenagogue, In a review, Dr. Monteiro da A stimulating.

da Silva co-workers, this plant potentiates other

antimalarial extracts and having potential use in malaria based on

ethnopharmacological

reports obtained in his expeditions.

Fever, jaundice, gallstone Indicated for malaria in the diarrhea, herpes, syphilis, colds, Flora Medicinal literature. flu, rheumatism, general Some doctors suggest that pruritus. Tonic, depurative. this plant could be tried if no chinchona bark or substitute is available.

Skin infections, dermatoses, Reported in review as a fever, malaria Oleaginous, resolutive.

Malaria, intermittent fever, adenitis, constipation, febrifuge.

Dyspepsias, gastric atony, fever, Reported as a substitute for infections, malaria. Tonic, quina in the treatment of astrigent, bitter, eupeptic, malaria in a review by Dr. febrifuge, antidiarrheal. Monteiro da Silva. Effective in malaria, but weaker tha Peruvian chinchona. plant used by the Amazonian malaria.

Indicated for malaria in the Flora Medicinal literature.
Isoquinolinic alkaloid-rich

$(42,43)$

plant with antiparasitary

Atlantic Forest.

Originary from the Amazon

Plant with African origin,

adapted to Brazil.

Plant from the Cerrado used for ornamenta purposes.

Herbaceous and rudera plant that occurs in almost all regions of Brazil, used also for ornamental purposes. It is described all South and Central America.

Plant from the Amazon tha is rich in coumarins, which gives it a special odor, and for this reason it has been used in the food and tobacco industry as an odorizing agent.

Herbaceous and ruderal plant that is found all over Latin America. writings and archives of Mr. Silva.

Medium sized tree that grows along the moist

lowlands of the Amazon.

Tree natural from the Southern and Southeast regions.

Tree that occurs in the Cerrado and Atlantic Forest. 
Table I: Plants with possible antimalarial activity gathered from ethnomedical reports published in Flora Medicinal (Continued)

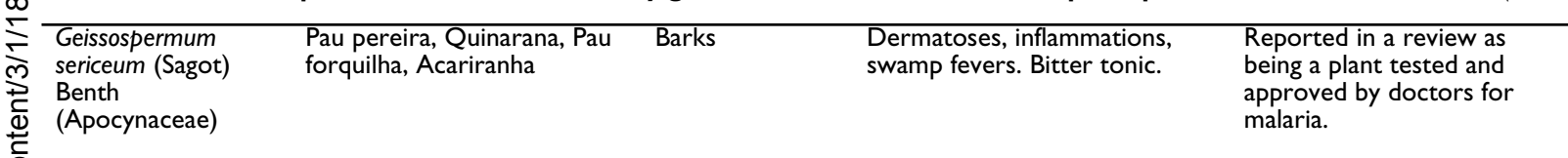

$\begin{array}{lll} & \\ \text { Alkaloids with activity } & \text { Species from the Atlantic } & (32,42,46) \\ \text { against Plasmodium } & \text { Forest. } \\ \text { falciparum were isolated } & \\ \text { from trees of the genus } & \end{array}$

Gomphrena Paratudo, Paratudinho,

Perpétua raiz do padre

(Amaranthaceae)

Leaves, flowers

roots fevers. Antithermal,

Use in malaria introduced by

Brazilian priests that learned

it from Indians.

Barks

emmenal, febrifuge, tonic,

upeptic, antitoxic, protector.

Himatanthus Agoniada, Plumeria

lancifolius (Mull. Arg) Agonium, Arapuê

Wood. Syn.

Plumeria lancifolia

Müll. Arg.

(Apocynaceae)

Jateorhiza palmata

Miers.

Calumba, Calunga

(Menispermaceae)

Melampodium Picão da praia, Fel da terra, divaricatum (L.C. Salsa da praia, Butter daisy Rich.) DC

(Asteracea)

\section{Mikania glomerata Guaco, Coração de Jesus,}

Spreng. (Asteracea)

Erva de cobr

Leaves and

Menstrual cramps, fever,

Use for malaria described by

Purgative, antispasmodic.

Pekolt among Guarani

Indians.

Barks

Flatulence, colic, diarrhea

Plant rich in quinolinic

alkaloids with antiparasitary

fever, emesis, nausea, infection, potential.

hypertension, bronchitis,

Bitter tonic, eupeptic.

Fever, malaria, flatulence,

Dr. Monteiro da Silva

muscular pain, palpitation, reports many cases of

vertigo, rheumatism, jaundice, extract of this plant.

anuria. Diuretic, carminative.

Rheumatism, snake poison,

intestinal problems, colics, reports to have observed

Dr. Pires de Almeida

政

outcomes.

Musa paradisiaca L. Banana, Bananeira Stem juice

Worms, diarrhea, intermittent Indicated by Dr. Monteiro da Silva to potentiate oth

Ocotea odorifera

(Vell.) Rohwer

Syn.Ocotea pretiosa

Sassafraz, Canela de

sassafraz, Sassafraz do Brasil,

Brazilian sassafras

plants used in malaria and

patients.

(Lauraceae)

Picrolemma sprucei Caferana, Caferana

verdadeira

(Simaroubacea)

Pradosia lactescens Bunhanhém, Pau de remo,

(Vell.) Radlk. Pau doce, Guaranhém,

Monesia
Barks and roots

Dermatoses, joint pain, fever, rheumatism, syphilis, gout Sudorific, depurative.

Indicated for malaria in the

Flora Medicinal literature.

One of the plants used by

Guarany Indians to treat

$\begin{array}{lll}\text { Aerial parts and } & \text { Malaria, intermittent fevers. } & \text { Dr. Monteiro da Silva } \\ \text { roots } & \text { Sudorific, depurative, febrifuge, } & \text { reports many cases of }\end{array}$

Sudorific, depurative, febrifuge,

antiinfectious.

recovery from malaria afte

treatment with the extract

of this plant.

$\begin{array}{ll}\text { Discharge, bronchitis, } & \text { Indicated for malaria in the } \\ \text { hemoptysis, diarrhea, ocular } & \text { Flora Medicinal literature. }\end{array}$

inflammation, tuberculosis, According to Dr. Monteiro

cutaneous ulcers, metrorrhagia. da Silva, this plant could be

Bark provides a milky juice that associated to any

is astringent and tonic. antimalarial therapeutic drug

if the patient is not
Plant natural from the

central region (Cerrado) of

as ornamental.

Plant that occurs in the

Cerrado and Atlantic

Forest.

Exotic plant, natural from

Africa, adapted to Brazil.

Worldwide distribution.

Liana that is common in the

Atlantic Forest.

Exotic plant adapted to

Species form the Atlantic

Forest.

Shrub that grows on solid

ground in the Amazon.

Species from the Atlantic

Personal

writings and

archives of $\mathrm{Mr}$

Monteiro da

Silva. 
Table I: Plants with possible antimalarial activity gathered from ethnomedical reports published in Flora Medicinal (Continued)

\begin{tabular}{|c|c|}
\hline $\begin{array}{l}\text { Quassia amara L. } \\
\text { (Simaroubacea) }\end{array}$ & $\begin{array}{l}\text { Quassia, Casca amargosa, } \\
\text { Pau amargo, Pau de surinã, } \\
\text { Quassia-wood, Surinam } \\
\text { quassia, Bitter quassia, } \\
\text { Bitterwood }\end{array}$ \\
\hline $\begin{array}{l}\text { Remijia ferruginea A. } \\
\text { St. Hil. (Rubiaceae) }\end{array}$ & Quina mineira \\
\hline $\begin{array}{l}\text { Simaba ferruginea A. } \\
\text { St. Hil. } \\
\text { (Simarubacea) }\end{array}$ & Calunga \\
\hline $\begin{array}{l}\text { Simarouba amara } \mathrm{L} \text {. } \\
\text { (Simaroubacea) }\end{array}$ & $\begin{array}{l}\text { Calunga, Marubá, Marupá, } \\
\text { Dysentery bark, Bitterwood, } \\
\text { Slave wood, Bitter damson }\end{array}$ \\
\hline $\begin{array}{l}\text { Strychnos } \\
\text { pseudoquina A. St. } \\
\text { Hil. (Loganiaceae) }\end{array}$ & $\begin{array}{l}\text { Quina do campo, Quina } \\
\text { branca, Quineira, Quina- } \\
\text { grossa, Quina do cerrado }\end{array}$ \\
\hline
\end{tabular}

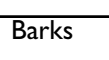

Gastric debility, dyspepsia,
blennorrhea, flatulence, fever,
malaria, diarrhea, worms. Bitter
tonic.

Barks Intermittent fever, malaria.

Barks and roots

Barks and roots

Malaria, fevers, diarrhea. Tonic, eupeptic, febrifuge, antidiarrheal, diuretic.

Intestinal infections, verminosis, Used by Amazonian Indians
fever, wounds, infected ulcers, $\begin{array}{ll}\text { abdominal pain. Antidiarrheal, } & \text { According to Dr. Monteiro }\end{array}$ $\begin{array}{ll}\text { antispasmodic, healing. } & \text { da Silva, it can be used in }\end{array}$

Splenomegaly, hepatomegaly, Cited by Dr. Monteiro da intermi

intermittent fever, malaria, febrifuge, depurative.

Tabebuia avellanedae Ipê roxo, Pau d'arco,

Barks

Fever, tumors, allergy,

weakness, psoriasis.

Antiinfectious, antifungic,

anticancer, tonic,

Infections, abdominal pain

worms, malaria. Digestive,
antiinflamatory, febrifuge.

Aubl. (Gentianacea) Caferana, Tinguá-aba

(n) and

Fever, tumors, malaria,

parasitosis. Antiinfectious, antifungic, anticancer, tonic immunestimulant.

malaria. Plant used in

Tabebuia Ipê preto, Ipê roxo, Ipê rosa, Barks Trumpet tree

(Bignoniaceae)

Xylopia brasiliensis

Spreng.

(Annonaceae)
Embira de caçador, Pindaíba Seeds and barks Stomachaches, flatulence,

malaria. Stom
febrifuge. but Dr. Monteiro da Silva

\section{According to a survey by Dr. Monteiro da Silva, it is used by Indians from the North of Brazil and from} treating malaria.

Cited by Dr. Monteiro da Silva as one of the species popularly used to substitute quina in
malaria.

Indicated for malaria in the Flora Medicinal literature According to Peckolt it was used by Amazonian Indians to treat malaria.

signs. quina in the treatment

Andra. According to

Andrade-Neto, its potency

is inferior to Peruvian quina with other antimalarial

plants.

Indicated for malaria in the

Flora Medicinal literature.

Should be added to

antimalarial regimens for

weak patients or in cases of

One of the plants cited by

Dr. Monteiro da Silva as

having potential for treating

Amazon by Indians to treat

malaria. reduction of $98 \%$ of infected red blood cells.

dicated for malaria in the Flora Medicinal literature.

Should be added to

antimalarial regimens for renal failure.

Indicated for malaria in the

Flora Medicinal literature,

considered it a weak

antimalarial drug.

\section{tracts showed}

experimental malaria in

mice.

Tested in mice with experimental malaria

A quassinoid isolated

from Simaba sp showed

activity against

Plasmodium falciparum in vitro.

Plant from the Amazonian

$(53,54$

Rainforest.

Medium sized tree that

occurs in Atlantic Rainforest

and South Amazonia.

Huge tree from the Amazon

Forest.

Big size tree that occurs in the Atlantic Rainforest and South Amazonia.

In a test with

experimental malaria in chicken caused by $P$. berghei, no activity was

ub from the Cerrado that produces edible fruits. Silva.
Personal writings and

Tree that occurs in the Cerrado and Atlantic Rainforest, with stron medicinal uses.

Personal writings and archives of Mr. Silva.

Personal writings and archives of $\mathrm{Mr}$ Monteiro da Silva. (47)

Tree that occurs in the Cerrado and Atlantic Rainforest, with stron

Personal writings and archives of Mr. Monteiro da Silva.

Xylopia sp extracts proved active against $P$. between 3 and $10 \mathrm{mcg}$ $\mathrm{ml}$.
Plant that occurs in the

Cerrado and Atlantic

Forest.
Personal writings and archives of Silva. (57) 


\section{References}

I. Khan MA, Smego RA Jr, Razi ST, Beg MA: Emerging drug-resistance and guidelines for treatment of malaria. J Coll Physicians Surg Pak 2004, 14:319-324.

2. Wernsdorfer $G$, Wernsdorfer $W H$ : Malaria at the turn from the 2nd to the 3rd millenium. Wien Klin Wochenschr 2003, I I 5:2-9.

3. Heggenhougen HK, Hackethal V, Vivek P: The behavioural and social aspects of malaria and its control. In Special Programme for Research \& Training in Tropical Diseases (TDR) Geneva: UNDP/ World Bank/WHO; 2003:12-52. 79-90

4. Farnsworth NR: Ethnopharmacology and drug development. Ciba Found Symp 1994, I 85:42-5I. discussion 5I-59

5. Mueller I, Namuigi P, Kundi J, Ivivi R, Tandrapah T, Bjorge S, Reeder JC: Epidemic malaria in the highlands of Papua New Guinea. Am J Trop Med Hyg 2005, 72:554-560.

6. Krettli AU, Andrade-Neto VF, Brandao MG, Ferrari WM: The search for new antimalarial drugs from plants used to treat fever and malaria or plants randomly selected: a review. Mem Inst Oswaldo Cruz 200I, 96: I033-I042.

7. The Missouri Botanical Garden's VAST [http:// mobot.mobot.org/W3T/Search/vast.html]

8. International Plant Names Index [http://www.ipni.org/ index.html]

9. New York Botanical Garden vascular plants database [http:l /www.nybg.org/bsci/hcol/vasc/]

10. Brazilian's Northeast Plants Database [http:// umbuzeiro.cnip.org.br/db/pnechk/taxa]

II. Addae-Kyereme J, Croft SL, Kendrick H, Wright CW: Antiplasmodial activities of some Ghanaian plants traditionally used for fever/malaria treatment and of some alkaloids isolated from Pleiocarpa mutica; in vivo antimalarial activity of pleiocarpine. J Ethnopharmacol 2001, 76:99-103.

12. Bertani S, Bourdy G, Landau I, Robinson JC, Esterre P, Deharo E. Evaluation of French Guiana traditional antimalarial remedies. I Ethnopharmacol 2005, 98:45-54

13. Bourdy G, Oporto P, Gimenez A, Deharo E: A search for natural bioactive compounds in Bolivia through a multidisciplinary approach. Part VI. Evaluation of the antimalarial activity of plants used by Isoceno-Guarani Indians. J Ethnopharmacol 2004, 93:269-277.

14. Breman JG, Alilio MS, Mills A: Conquering the intolerable burden of malaria: what's new, what's needed: a summary. $A m$ J Trop Med Hyg 2004, 7 I: I- I5.

15. Cabral MM, Azambuja P, Gottlieb OR, Kleffmann T, Garcia ES, Schaub GA: Burchellin: effects on Triatoma infestans and on Trypanosoma cruzi within this vector. Parasitol Res 200I, 87:730-735.

16. Carvalho LH, Brandao MG, Santos-Filho D, Lopes JL, Krettli AU: Antimalarial activity of crude extracts from Brazilian plants studied in vivo in Plasmodium berghei-infected mice and in vitro against Plasmodium falciparum in culture. Braz J Med Biol Res 1991, 24:1113-1123.

17. do Ceu de Madureira M, Paula Martins A, Gomes M, Paiva J, Proenca da Cunha A, do Rosario V: Antimalarial activity of medicinal plants used in traditional medicine in $S$. Tome and Principe islands. J Ethnopharmacol 2002, 8I:23-29.

18. Courtois M, Mincheva Z, Andreu F, Rideau M, Viaud-Massuard MC: Synthesis and biological evaluation with plant cells of new fosmidomycin analogues containing a benzoxazolone or oxazolopyridinone ring. J Enzyme Inhib Med Chem 2004 , 19:559-565.

19. Etkin NL: The co-evolution of people, plants, and parasites: biological and cultural adaptations to malaria. Proc Nutr Soc 2003, 62:311-317.

20. Hay SI, Guerra CA, Tatem AJ, Noor AM, Snow RW: The global distribution and population at risk of malaria: past, present, and future. Lancet Infect Dis 2004, 4:327-336.

21. Lee MR: Plants against malaria. Part I: Cinchona or the Peruvian bark. J R Coll Physicians Edinb 2002, 32:189-196.

22. MacKinnon S, Durst T, Arnason JT, Angerhofer C, Pezzuto J, SanchezVindas PE, Poveda LJ, Gbeassor M: Antimalarial activity of tropical Meliaceae extracts and gedunin derivatives. I Nat Prod 1997, 60:336-34I.

23. Milliken W: Plants for Malaria; Plants for Fever Kew: Royal Botanic Gardens; 1997

24. Muregi FW, Chhabra SC, Njagi EN, Lang'at-Thoruwa CC, Njue WM, Orago AS, Omar SA, Ndiege IO: In vitro antiplasmodial activity of some plants used in Kisii, Kenya against malaria and their chloroquine potentiation effects. J Ethnopharmacol 2003, 84:235-239.

25. Randrianarivelojosia $M$, Rasidimanana VT, Rabarison $H$, Cheplogoi PK, Ratsimbason M, Mulholland DA, Mauclere P: Plants traditionally prescribed to treat tazo (malaria) in the eastern region of Madagascar. Malar J 2003, 2:25

26. Rasoanaivo P, Petitjean A, Ratsimamanga-Urverg S, Rakoto-Ratsimamanga A: Medicinal plants used to treat malaria in Madagascar. J Ethnopharmacol 1992, 37: I I7-I27.

27. Rath K, Taxis K, Walz G, Gleiter CH, Li SM, Heide L: Pharmacokinetic study of artemisinin after oral intake of a traditional preparation of Artemisia annua L. (annual wormwood). Am J Trop Med Hyg 2004, 70:128-1 32.

28. Sanon S, Ollivier E, Azas N, Mahiou V, Gasquet M, Ouattara CT, Nebie I, Traore AS, Esposito F, Balansard G, Timon-David P, Fumoux $F$ : Ethnobotanical survey and in vitro antiplasmodial activity of plants used in traditional medicine in Burkina Faso. J Ethnopharmacol 2003, 86: I43-I47.

29. Waller RF, Ralph SA, Reed MB, Su V, Douglas JD, Minnikin DE, Cowman AF, Besra GS, McFadden GI: A type II pathway for fatty acid biosynthesis presents drug targets in Plasmodium falciparum. Antimicrob Agents Chemother 2003, 47:297-301.

30. Weniger B, Robledo S, Arango GJ, Deharo E, Aragon R, Munoz V, Callapa J, Lobstein A, Anton R: Antiprotozoal activities of Colombian plants. J Ethnopharmacol 200I, 78:193-200.

31. Zirihi GN, Mambu L, Guede-Guina F, Bodo B, Grellier P: In vitro antiplasmodial activity and cytotoxicity of 33 West African plants used for treatment of malaria. J Ethnopharmacol 2005 , 98:281-285

32. Revista da Flora Medicinal, Aug. 1938.

33. Revista de Flora Medicinal, July 1945.

34. Sanon S, Azas N, Gasquet M, Ollivier E, Mahiou V, Barro N, CuzinOuattara N, Traore AS, Esposito F, Balansard G, Timon-David P: Antiplasmodial activity of alkaloid extracts from Pavetta crassipes (K. Schum) and Acanthospermum hispidum (DC), two plants used in traditional medicine in Burkina Faso. Parasitol Res 2003, 90:314-317.

35. Revista da Flora Medicinal, Mar. 1935.

36. Revista da Flora Medicinal, Nov. 1948.

37. Barroso SM: Fitoterapia e Medicina Científica Rio de Janeiro: Laboratório Flora Medicinal; 1953.

38. Costa DAM: A Malaria e Suas Diversas Modalidades Clínicas Rio de Janeiro: Lombaerts \& Co; 1885

39. Andrade-Neto VF, Brandao MG, Oliveira FQ, Casali VW, Niaine B Zalis MG, Oliveira LA, Krettli AU: Antimalarial activity of Bidens pilosa L. (Asteraceae) ethanol extracts from wild plants collected in various localities or plants cultivated in humus soil. Phytother Res 2004, I 8:634-639.

40. Revista da Flora Medicinal, May 1935.

41. Peckolt G, Peckolt F: História das Plantas Medicinais e Úteis do Brasil Rio de Janeiro: Companhia Typographica do Brasil; 1853.

42. Revista da Flora Medicinal, July 1940.

43. Revista da Flora Medicinal, July 1935.

44. Revista da Flora Medicinal, June 1938.

45. Revista da Flora Medicinal, Nov. 1942

46. Steele JC, Veitch NC, Kite GC, Simmonds MS, Warhurst DC: Indole and beta-carboline alkaloids from Geissospermum sericeum. J Nat Prod 2002, 65:85-88.

47. Caminhoá JM: Elementos de Botânica Médica Rio de Janeiro: Typographia Nacional; 1877.

48. Revista da Flora Medicinal, Aug. 1941.

49. Revista da Flora Medicinal, Nov. 1941.

50. Revista da Flora Medicinal, Mar. 1938.

51. Revista da Flora Medicinal, Mar. 1942.

52. Revista da Flora Medicinal, Fev. 1942.

53. Revista da Flora Medicinal, July-Dec. 1952.

54. Ajaiyeoba EO, Abalogu UI, Krebs HC, Oduola AM: In vivo antimalarial activities of Quassia amara and Quassia undulata plant extracts in mice. J Ethnopharmacol 1999, 67:321-325.

55. Andrade-Neto VF, Brandao MG, Stehmann JR, Oliveira LA, Krettli $\mathrm{AU}$ : Antimalarial activity of Cinchona-like plants used to treat fever and malaria in Brazil. J Ethnopharmacol 2003, 87:253-256. 
56. Moretti C, Deharo E, Sauvain M, Jardel C, David PT, Gasquet M: Antimalarial activity of cedronin. J Ethnopharmacol 1994, 43:57-61.

57. Jenett-Siems K, Mockenhaupt FP, Bienzle U, Gupta MP, Eich E: In vitro antiplasmodial activity of Central American medicinal plants. Trop Med Int Health 1999, 4:6 I I-6I5.

58. Normark $\mathrm{BH}$, Normark S: Evolution and spread of antibiotic resistance. J Intern Med 2002, 252:9I- 106.

59. Sanchez CP, Stein W, Lanzer M: Trans stimulation provides evidence for a drug efflux carrier as the mechanism of chloroquine resistance in Plasmodium falciparum. Biochemistry 2003, 42:9383-9394.

60. Jones $R N$ : The current and future impact of antimicrobial resistance among nosocomial bacterial pathogens. Diagn Microbiol Infect Dis 1992, 15:3S-10S.

61. Fernandes P, Ferreira BS, Cabral JM: Solvent tolerance in bacteria: role of efflux pumps and cross-resistance with antibiotics. Int J Antimicrob Agents 2003, 22:2 I I-2 I6.

62. Trotta RF, Brown ML, Terrell JC, Geyer JA: Defective DNA repair as a potential mechanism for the rapid development of drug resistance in Plasmodium falciparum. Biochemistry 2004, 43:4885-4891.

Publish with Bio Med Central and every scientist can read your work free of charge

"BioMed Central will be the most significant development for disseminating the results of biomedical research in our lifetime. "

Sir Paul Nurse, Cancer Research UK

Your research papers will be:

- available free of charge to the entire biomedical community

- peer reviewed and published immediately upon acceptance

- cited in PubMed and archived on PubMed Central

- yours - you keep the copyright

Submit your manuscript here:

http://www.biomedcentral.com/info/publishing_adv.asp 